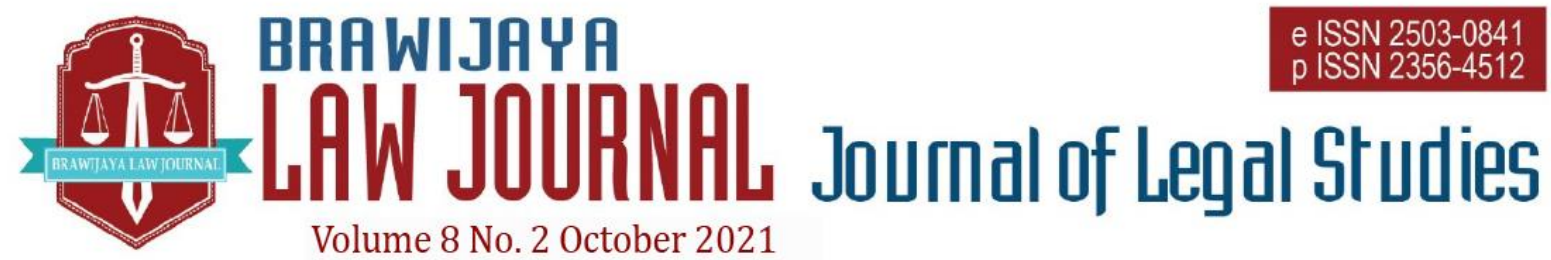

Nationally Accredited No. 30/E/KPT/2018 Dated 24th October 2018

This work is licensed under a Creative Commons Attribution-NonCommercial 4.0 International License

\title{
Covid 19 in the face of Contemporary International Law
}

\author{
Nima Norouzi ${ }^{1 *}$, Elham Ataei ${ }^{2}$ \\ ${ }^{1}$ School of Law, Department of Human Sciences, Islamic Azad University, Tehran, Iran \\ *Email: n.nima1376@gmail.com \\ ${ }^{2}$ School of political science and international relationships, Payam Noor University, Tehran, \\ Iran.
}

Submitted: 2021-08-10 | Accepted: 2021-09-26

\begin{abstract}
The outbreak of Covid-19 is an international crisis that has been unprecedented for the past hundred years. The virus was first reported in Wuhan, China, in late 2019 and gradually spread worldwide. In such circumstances, the effectiveness of international law in protecting human lives and promoting the right to health has been severely tested. More importantly, in the words of Michel Bachelet (A UN official), the Covid-19 has become a benchmark for the international community. This article will analyze how international law deals with the Covid-19 crisis in several areas: first, the World Health Organization's role as the main body responsible for protecting human healthcare in the face of the Covid-19 outbreak will be analyzed. Second, the international responsibility of States in guaranteeing the right to health will be assessed to determine the effectiveness of international law. Third, the suspension of human rights abuses due to the Covid-19 outbreak emergency will be tested in the international human rights system. Finally, the performance of the UN Security Council in dealing with this pandemic is examined. In each area, the question is to what extent the current structure of international law effectively deals with international crises and preserves human dignity.
\end{abstract}

Keywords: covid-19, international law, world health organization, united nations security council, international responsibility of governments, state of emergency

\section{INTRODUCTION}

The outbreak of Covid-19 is an international crisis that has been unprecedented in the last hundred years. The first outbreak of Covid-19 in Wuhan, China, in early December 2019 gradually spread to the rest of the world. ${ }^{1}$ According to global statistics, as of early July 2020, more than 15 million people worldwide have contracted this dangerous disease, from which a significant number of them have lost their lives. In such circumstances, the effectiveness of international law in protecting human lives and promoting the right to health has been rigorously tested. More importantly, according to the UN High Commissioner for Human Rights (Michel Bachelet), the Covid-19 has become a

1 Montel, Lisa, et al. "The Right to Health in Times of Pandemic: What Can We Learn from the UK's

Response to the COVID-19 Outbreak?." Health and Human Rights 22.2 (2020): 227. 
benchmark for the international community. ${ }^{2}$ The crisis caused by the Covid-19 outbreak has attracted the attention of many philosophers and thinkers. Covid-19 is a crisis whose scope is in a state of ambiguity. Experts are skeptical about the dangerous extent of the virus, to the point where some leading experts believe that governments and even the World Health Organization, despite some claims, have not yet found a definitive cure for the disease.

Furthermore, it is unclear how long this dangerous virus will affect human life. Philosophers have analyzed the inability of human society to deal with this deadly virus of philosophical theories, analyzing each from its perspective. Sociologists have also made the Covid-19 the subject of sociological debate, particularly the phenomenon of "correlation" more than ever. The truth is that human beings in the current situation need "international solidarity" to overcome this global crisis. ${ }^{3}$

Lawyers have also analyzed this international crisis from various angles. A group of international jurists, looking at this international crisis from the government's international responsibility perspective, has addressed China's international responsibility. Some jurists claim that the Chinese government, aware of the spread of this deadly virus, has refrained from providing sufficient information to the international community. Of course, the veracity of any claim requires the presentation of conclusive evidence, and Ali

2 For current statistics on coronavirus infections and victims, see https://www.worldometers.info/coronavirus/

3 coronawhistleblower.org/wp-content/ uploads / 2020/05 / Ventegodt- Merrick- A- tribute- to- theCorona- virus- COVID- 19- SARS-CoV- 2whistle-blowers-JAMR-2020-12-2_02.pdf.

4 For a discussion of Chinese government liability for coronary heart disease, see https://www.amnesty.org/en/latest/news/2020
al-Qaeda's research papers cannot prove the international responsibility of a state; The point is, the Covid-19 has caused such controversy in the scientific community. ${ }^{4}$

In addition, according to UN experts, the outbreak of the Covid-19 has led to racist attacks and attacks on Asians in some cases. ${ }^{5}$ Similarly, UN experts have stated that racist comments related to the Covid-19 should be stopped. However, the prevalence of that crisis over racial discrimination has also become more pronounced. ${ }^{6}$ The Covid-19 has also hampered the implementation of international economic law and international trade law. Governments have closed their borders under the pretext of countering the spread of the Covid-19, and traders, business people, and owners of industries and transportation companies have almost stopped working. For this reason, the virus has re-raised the issue of possible conflict of trade with human rights. The principle of freedom of trade requires the free movement of traders and goods, but freedom of movement and goods can kill people in the current crisis. Also, in the current situation, many traders have failed to fulfill their contractual obligations due to the prevalence of Covid-19. ${ }^{7}$

In addition, the Covid-19 will have profound and far-reaching implications for the immigration policies of some governments. For example, the president of the United States has spoken of his country's highly contractionary policy to address the Covid-19 problem and the plight of refugees

5 Sam Zarifi, Covid-19 symposium: Human rights in the time of Covid-19-front and center, in: Covid-19 and international law, opinion juris symposium, p. 127.

6 Villarreal, Pedro A. "Pandemic: Building a Legal Concept for the Future." Wash. U. Global Stud. L. Rev. 20 (2021): 611.

7 For the UN Expert Report, see https://www.ohchr.org/EN/NewsEvents/Pages/Di splayNews.aspx?NewsID=25739\&LangID=E. 
in deep crisis. ${ }^{8}$ Many governments now close their borders to asylum seekers and even deport them under the pretext of fighting the Covid-19. Although sovereignty and territorial jurisdiction are inherent elements of international law, the Covid-19 does not recognize borders; This uninvited guest easily crosses national borders and ironically ridicules international law. The other is whether those countries are not in crisis. Right now, all governments and all human beings are battling a deadly disease called Covid-19. ${ }^{9}$

Covid-19 has revealed the hidden contradictions of human society. Until the 2010s, racism was a problem of the international community, and today the Covid-19 has highlighted such a problem, and a group of people allows themselves to insult a certain race instead of treating and combating the virus (and not disease) as the cause of death. Until recently, the issue of helpless asylum seekers was among the contradictions of the international community, and the Covid-19 has doubled the homeless problems. Until recently, poverty and helplessness revealed the contradiction between the rich and the poor today, and the Covid-19 shows this contradiction more than ever so that some people use the best and most equipped medical equipment to save and revive their lives.

On the other hand, another group is deprived of medical equipment due to poverty and is forced to die silently. ${ }^{10}$ The bottom line is that the Covid-19 has made it so much more, and as a shining light, it has exposed the contradictions of the forty-

\footnotetext{
${ }^{8}$ https://www.theguardian.com/world/2020/apr/21/tru mp-says-he-willimpose-immigration-ban-in-bidto-tackle-coronavirus

9 Sam Zarifi, Covid-19 symposium: Human rights in the time of Covid-19-front and center , in: Covid-
}

something and more or less dark society of the international community. The question now is to what extent the crisis caused by Covid-19 has revealed the efficiency or inefficiency of the legal system governing the (international) society. It seems that this crisis has not only posed a very serious challenge to the inefficiency of this system in the field of public health but has also been able to have a significant impact on the future of this legal system. The article first refers to the "efforts" of governments and their institutions to combat the Covid-19, and then the impact of this crisis, which has posed a deadly challenge to human life, on the international legal system.

\section{LEGAL MATERIALS AND METHOD}

The method applied in this study is juridical normative. This research uses data collection techniques based on documentation and library research by collecting data and information from various sources of documents and literature, including:

a. International Health Regulations (1969).

b. International Health Regulations (2005).

c. The 1948 Universal Declaration of Human Rights.

d. The Charter of the United Nations in 1945.

e. Law no. 39 of 1999 concerning Human Rights.

f. Vienna Convention on the Law of Treaties.

\section{RESULTS AND DISCUSSIONS Global Health Regulations Framework of Government Obligations in the Face of Covid-19}

\section{a. Position of the World Health Organization (WHO)}

19 and international law, opinion juris symposium, p. 127.

10 Odom, Jonathan G. "COVID-19 and the Law: A Compilation of Legal Resources." Available at SSRN 3588225 (2021). 
Since the founding of the World Health Organization in 1948, it has been primarily responsible for maintaining international health. In 2005, the General Assembly of this international body published the second version of the Universal Declaration of Health; The document has been in force since 2007. The 1969 version inspires the 2005 revised version. Global health regulations are not a treaty but a binding document. This binding document is based on Article 21 of the Statute of the World Health Organization. Article 21 of the organization's charter allows its general assembly to adopt binding regulations to combat the spread of epidemics. If the General Assembly of the World Health Organization adopts a charter to combat the spread of communicable diseases, that charter is binding on the organization's member states without the need for subsequent ratification. It has been used following Article 21 of its Articles of Association global health regulations will be ignored. ${ }^{11}$

Article 2 of the 2005 World Health Regulations states that this regulation aims to prevent and control the spread of international diseases. The purpose of prevention is to take measures to prevent the spread of infectious diseases. However, if infectious diseases spread internationally due to an outbreak, measures will be taken to control the outbreak of the disease, i.e., to limit it. Article 2 of the World Health Regulations adds that preventing and controlling infectious diseases should not harm trade.

Infectious diseases such as Covid-19 are rapidly transmitted from country to

11 Of course, according to Article 22 of the Statute of this organization, approved bylaws are mandatory, with the exception of states that have been notified of their acceptance or conditional actions within the deadlines set for the Director General. country. The phenomenon of globalization can also accelerate the spread of infectious diseases. Every day, passengers are transported from one country to another by ship, plane, and train; International travelers, can transmit infectious diseases to other countries from their country of residence. Therefore, tackling the spread of infectious diseases requires extensive international cooperation. As the world's leading health authority, the World Health Organization must be aware of the risks of communicable diseases to make the right decisions promptly. For this reason, following Article 6 of the Universal Declaration of Health, States must notify the organization of a public health hazard within 24 hours. ${ }^{12}$

According to paragraph 3 of Article 13 of the World Health Regulations, after receiving information from the country where the disease has spread, the World Health Organization is obliged to cooperate with the country infected with the contagious disease to deal with the spread of the disease. This cooperation can take the form of providing technical assistance. In addition, if necessary, the organization can assist by sending international experts to the country where the outbreak occurs.

Timely awareness of the prevalence of infectious diseases can control the risk of their spread. As a result, countries can respond more quickly and appropriately as soon as they become aware of the spread of such diseases. For this reason, Article 11 paragraph 1 of the World Health Regulations obliges the World Health Organization to receive regular information on the prevalence of the disease from all countries and to make

12 Villarreal, Pedro A. "Pandemic: Building a Legal Concept for the Future." Wash. U. Global Stud. L. Rev. 20 (2021): 611. 
such information available to other States. At the time of an infectious disease outbreak, the spread of that disease will likely be limited within a country's borders. On the other hand, there is another possibility that the disease is so strong and rapidly spreading that its spread will spread quickly to other countries. For this reason, determining the importance, severity, and severity of this type of disease, especially the possibility of its international transmission, is of great importance. Article 12 of the World Health Organization entrusts determining the severity and severity of infectious diseases to the World Health Organization Director.

\section{b. Global health regulations against Covid-19}

Dealing with infectious diseases requires reactive and excretory measures against the sudden outbreak of these diseases. The outbreak of these diseases could put thousands of citizens at risk of death. In such a situation, the country's medical and health infrastructure must be ready to treat patients in advance. The number of hospital beds in the country should host a sufficient number of patients. Patients are at risk of death if medical and hospital equipment is not adequate. However, building hospitals and treatment centers and equipping them takes time. States have a long-term plan to build and equip hospitals; For this reason, some of the governments' commitments to tackling epidemics are so-called "long-term commitments." For example, according to Articles 5, 6, and 13 of the Global Health Regulations, governments must build capacity to combat communicable diseases.

Paragraph 1 of Article 3 of these regulations states: "The implementation of these regulations must be carried out with full respect for human dignity, human rights, and fundamental freedoms." In this regard, Article 32 of the Universal Declaration of Health provides: "In implementing health measures following these regulations, States Parties shall treat all travelers following the standards of human dignity, human rights, and fundamental freedoms." Articles 31, 32, 40, and 42 of the Universal Declaration provide for standard health concerning the entry and exit of passengers into borders during the outbreak of infectious diseases. During the outbreak of communicable diseases, the rights of travelers and the right to travel are overshadowed. Can governments restrict the entry and exit of passengers due to the spread of epidemics? In this case, Article 31 of the Universal Health Regulations stipulates that, in principle, governments cannot restrict the entry and exit of passengers; Unless there are serious hazards that threaten public health. In addition, governments cannot, in principle, compel travelers to undergo medical examinations and vaccinations unless there are serious public health hazards. ${ }^{13}$

Also, when outbreaks occur, the rights of travelers will likely conflict with health regulations. For example, if a traveler wants to enter a country at risk of contracting a contagious disease, the government can ask that traveler to undergo a medical examination. In such an assumption, if the passenger refuses to undergo a medical examination, the question arises as to whether the government can not allow the passenger to enter the country. In the legal explanation of such a situation, paragraph 2 of Article 31 of the World Health Regulations states that the traveler's first

13 Villarreal, Pedro A. "Pandemic: Building a Legal Concept for the Future." Wash. U. Global Stud. L. Rev. 20 (2021): 611. 
consent to a medical examination or vaccine injection is required. Second, if the passenger refuses to undergo a medical examination or vaccination, the government can prevent passengers from entering its territory under certain conditions. However, if the risk of an outbreak and the disease is high, the government can compel the traveler to undergo a medical examination, vaccination, or precautionary measures such as quarantine as necessary.

According to Article 32 of the World Health Regulations, if states establish public health towards passengers, they must treat passengers with the utmost respect and courtesy. In addition, governments should consider gender, social and cultural status, and the religious and ethnic status of the traveler when adopting health measures. Any of these situations can put the passenger in a fragile and vulnerable position. For this reason, governments must treat more vulnerable travelers with more respect and courtesy. For example, due to the fragility and vulnerability of women and children, it is necessary to be more polite and respectful towards them. If dealing with the outbreak of diseases requires quarantine or vaccination of travelers, the issue of paying for their accommodation in special quarantine accommodation or vaccination costs is of great importance; In general, these costs can be borne by passengers or the government, but due to the observance of passengers' rights, Article 40 of the Universal Health Regulations obliges governments to cover the costs associated with public health measures. For example, if passengers on a foreign flight enter another country and it is necessary to vaccinate them, the government cannot impose the cost of vaccinating the passengers on them. In other words, governments are, in principle, primarily responsible for paying the general costs of health care. Of course, the government's principle of payment of health costs also has exceptions; If States wish to charge passengers health expenses following the provisions of Article 40 of the International Regulations, the charges shall not exceed the cost price. In other words, health expenses will only be received as much as necessary, and governments have no right to make a profit under the pretext of providing health services. Also, the receipt of health expenses must have a fixed and fixed tariff. Governments are also required to adhere to the principle of non-discrimination when receiving health care costs. This means that governments do not have the right to impose discrimination based on travelers' accommodation and even their nationality when receiving health care costs. Article 40 of the World Health Regulations provides another form of health insurance; If the government wants to change the tariff to provide health services, it must inform the public of the new tariff ten days in advance.

Article 43 of the Global Health Regulations allows governments to take additional measures to establish public health and combat communicable diseases. Article 42 of these regulations sets out three general principles for applying health regulations: First, sanitary measures must be adopted immediately and without delay. Adherence to this principle is necessary because the fight against pervasive diseases requires urgency, not delay. Delays in government action on public health can have disastrous and catastrophic consequences. Second, hygienic measures must be taken following the principle of transparency; Observance of transparency requires that the government refrain from concealment and that the general public observe the government's actions in establishing public health. Third, the government must adhere to non- 
discrimination in establishing public health and combating communicable diseases. This means that governments should not discriminate or refrain from providing health services to individuals based on their gender, race, religion, or ethnicity. As noted, global health regulations are a binding document; Violating the provisions of this binding document will result in the international responsibility of the offending government. For example, as mentioned earlier, the government is obliged to inform the prevalence of infectious diseases within 24 hours; Now, if the government does not fulfill its duty to inform about the contagious disease, it will have international responsibility.

The International Law Commission has also defined the concept of "disaster" so broadly in its draft articles on the protection of persons in the event of disasters that it also includes pervasive diseases (paragraph $\mathrm{A}$ of Article 3 of the draft). ${ }^{14}$ According to Article 11 of the said draft, if the government cannot control disasters and catastrophes, it must ask for help from the international community. Although assistance to a country affected by a catastrophe requires its consent, such consent should not be arbitrarily waived (paragraph 2 of Article 13 of the draft law of the International Law Commission). The World Health Organization's oversight of governments' commitments to global health regulations is important. If the organization's member states violate their obligations as contained in the health regulations, the World Health Organization can not invoke the responsibility of the offending state. In other words, the World Health Organization has no

14 Bartolini, Giulio. "A universal treaty for disasters? Remarks on the International Law Commission's Draft Articles on the Protection of Persons in the Event of Disasters." International Review of the Red Cross 99.906 (2017): 1103-1137. authority to pursue the state's responsibility for violating the regulations. The only existing executive mechanism is that a report on non-compliance with global health is submitted to the General Assembly of the World Health Organization. ${ }^{15}$

The Director-General of the World Health Organization may also issue recommendations to address the prevalence of infectious diseases. For example, on 30 January 2020, he issued a letter of recommendation banning travel to the People's Republic of China, particularly Wuhan Province. However, if the Director General's recommendations are violated, there is no guarantee of enforcement against the violation. The World Health Organization does not act as a global police force. Instead, the organization acts only as a technical institution and, in its duties, issues recommendations to deal with the spread of infectious diseases.

\section{International Healthcare Responsibility of Governments}

The international health law has received more attention with the outbreak of Covid-19. Undoubtedly, the activities of the World Health Organization in the field of disease control, including infectious diseases such as SARS, AIDS, and Ebola, have been noteworthy; However, since the outbreak of Covid-19 disease, the organization has not received as much attention; It is as if it has become a small Security Council to which all eyes are on. Governments, individuals, and national and international institutions await the day-to-day findings of this organization. Perhaps the necessities of the international

15 Covid-19 symposium: "can they really do that?", state obligations under the International Health Regulations in light of Covid-19, Pedro A. in: Covid-19 and international law, opinion juris symposium, p. 23. 
community require that, after all, human beings have coexisted peacefully with this disease at best. It is not unreasonable to expect that the role of this organization in the future will go beyond a regulatory organization and become the inevitable arm of the international community in determining what the preservation of international peace and security is. This disease targets the human person. However, the fundamental question from a legal point of view is whether the state of the oldfashioned nations can become ill. As of this writing, the answer is yes; Incidentally, this disease is one of the few examples that has been proven that governments, regardless of the degree of progress and development, may not be able to effectively control the outbreak of the disease and deal with it and therefore be considered incapable. Therefore, the concept of disability is no longer limited to governments such as Somalia, Afghanistan, etc., and now all governments have somehow lacked a standard of effective control.

With this description, another fundamental question is whether governments can be held internationally responsible for the prevalence of the disease. First of all, it should be made clear that in this regard, the issue should be following the International Government Responsibility Plan adopted in 2001, which contains the secondary rules of international law, as a handbook of government responsibility, as well as the International Health Organization and the World Health Organization. International human rights instruments should be considered as basic rules.

From the 2001 Liability Plan perspective, states have specific international responsibility for the conduct of international offenses (including acts and omissions). For international responsibility to be realized, two elements must coexist: it can be attributed to government action, and the other is that it is internationally offensive. It is also clear that several governments may have committed that offense; Second, the 2001 liability plan clarifies that the element of fault does not play a role in that action, although it may affect the effects of international liability, including the issue of compensation. With this explanation, it can be assumed that a government may have international responsibility not only because of its stewardship in the spread of Covid-19 but also because of its lack of timely prevention and information and its failure to provide the necessary measures to prevent it, regardless of the element of fault in this regard. It should be noted that sometimes in the second paragraph, negligence in prevention, both primary and secondary rules, can be decisive. Now, concerning the above points, it is necessary to address the basic rules governing the international issue of health. It is necessary to address this issue to determine the content of the international obligations of States in this regard and secondly to determine whether the alleged violations are attributable to States and that the international obligation in principle has been violated. International law applicable in international health should be considered in the statute of the World Health Organization and its resolutions. The forty-fifth edition of this statute was approved in 2006. The preamble to the charter contains points on states' international obligations, including the principle of international cooperation. It is also stated in the introduction that health is a human right and is linked to the issue of international peace and security.

Therefore, the general atmosphere of the preamble to the statute is a reflection of Saadi Shirazi's poem: "When a member hurts the times, there are no other members left." An important point in this regard is the part 
of the preamble which states: "Governments have a responsibility for the health of their people, which can only be achieved by providing the standards of the Legal Research Quarterly - Special Issue of Law and Covid-19 in the Mirror of Contemporary International Health and Social Law". It should be noted that the Statute of the World Health Organization is a treaty. According to the Vienna Convention on the Law of Treaties of 1969 , the preamble to the treaty is a context of the treaty and effectively interprets the treaty's provisions. In addition, the commitments of member states and other relevant members are set out in the Statute of the World Health Organization. Perhaps what attracts the most attention can be seen in Articles 61 to 68 of the Articles of Association. In this set of materials, governments have made commitments; These include: submitting an annual report on public health, an annual report on how the organization's decisions regarding agreements, conventions, and regulations are implemented, as well as a commitment to promptly submit important laws and regulations and reports and statistics on health. The government has published, providing statistical and epidemiological reports in the manner determined by the Health Assembly, and the transmission of additional health-related information at the council's request and, as far as practicable.

According to Article 56 of the World Health Regulations, governments can negotiate and mediate to resolve their disputes. This means that any member state of the organization can enter into resolving disputes by invoking the responsibility of the offending state. If the negotiation and mediation process is not successful and the parties to the dispute cannot reach a peaceful settlement, Article 56 of the Universal Health Regulations allows the parties to the dispute to refer their dispute to the arbitral tribunal, particularly the Permanent Court. Thus, in the event of a dispute, the World Health Organization member states may refer to the arbitral tribunal and ask the arbitral tribunal to assume the liability of the offending state and order compensation for damages. In this regard, Article 75 of the Statute of the World Health Organization can also be mentioned. According to this article, "Any issue or dispute regarding the interpretation or application of this statute that is not resolved through negotiations or the Health Assembly shall be referred to the International Court of Justice following the Statute of the Court; Unless the parties agree otherwise. In addition, following Article 76 of this instrument, the organization may, following its authorization from the General Assembly, following its agreement with the United Nations, consult the International Court of Justice on any matter relating to its competence. At present, almost all governments are struggling with the disease. The World Health Organization declared a state of emergency and declared the disease epidemic on 11 March 2020. Many governments have taken many steps to prevent the disease further. It is also clear that the disease originated in China. Now, because of the above points, it is necessary to address whether there has been a fundamental violation of the international obligation in this regard. The solution to this problem is noteworthy given the heavy blows this disease has dealt with the economies of governments. In particular, the arrow's tip is towards the Chinese government, and there have even been discussions about filing a lawsuit against China in the International Court of Justice. As events show, all governments, including China, have taken immediate steps to control the disease and live up to their long-term commitments. 
These measures include quarantine, social distancing, travel restrictions, etc., and demonstrate the commitment of states to maintain health. The obligations contained in the Statute of the World Health Organization are so general that it may not be possible to specify which government has exactly violated those obligations. In addition to the treaty and customary sources, reference should be made to the general principles of international law, including the principle of due diligence and the principle of precaution. Do not forget that the two elements of attributing and committing international wrongdoing are necessary to achieve international responsibility. Even with due diligence and precaution principles, the facts do not show that governments have not taken due care. In addition, there are cases in the liability plan in which a state can be exempted from international liability. Among these factors, including consent, legitimate defense, reciprocal action, necessity, urgency, and force majeure, the last three factors are the most relevant factors that remove the description of the offense of an international offense. Therefore, even in international wrongdoing, it is possible to absolve oneself of responsibility in this particular case. Finally, because the lack of effective control over the territory in the plan of responsibility can lead to the irresponsibility of a state, for example, against the illegal actions of insurgent groups, and assuming the lack of effective control of states against this disease, the international responsibility of these governments. It makes the field difficult. Therefore, the placement of general and general legal obligations, at least within the framework of the World Health

16 UN General Assembly, Universal Declaration of Human Rights, 1948.
Organization, in the field of health in the face of developments that indicate the actions of all governments to combat this disease, presupposes a violation of international obligations following international law. The International Government Responsibility Plan, adopted in 2001, is in question. There have been many efforts to formulate and explain "shared responsibility" over the past few years at the academic level. Achieving such a framework means modifying the current system of international responsibility, which is based on the individual responsibility of governments. However, these efforts do not reflect existing international law. So what to do? Perhaps not all problems should be attributed to secondary rules. The fact is that the fundamental flaws in the system of basic rules governing global health. First, these problems are due to the lack of specific obligations and explanation of the details of the right to health. More detailed rules can probably be found in human rights documents. However, the World Health Organization relationship, the main center of world health management, is not clear with these commitments. The second problem is that the powers of the World Health Organization are limited, and its charter places the organization only at the level of a regulatory organization. The international community needs to require that the organization's statute be amended as soon as possible and given wider powers. ${ }^{16}$

\section{The Covid-19 and the obligations of governments towards the right to health}

\section{a. What right and what obligation? Conceptual analysis}


Article 25 of the Universal Declaration of Human Rights speaks of the right to health. Article 12 of the Covenant on Economic, Social, and Cultural Rights also classifies the right to health as a human right. General Theory No. 14 of the Committee on Economic, Social, and Cultural Rights has described and interpreted the right to health. Protecting public health is not only a task; it takes precedence over other tasks. Governments are obliged to guarantee the right to public health without any discrimination. The right to health is the most important human right because the fulfillment of any human right depends on people's physical and mental health. The right to health belongs to all human beings, and all individuals, regardless of their nationality, can claim the right to health from the government. This means that everyone, whether a citizen of the country of residence or an immigrant or refugee, can claim the right to health. In other words, the right to health does not belong only to the citizens of one country, and everyone can claim such a right. ${ }^{17}$

The right to health requires that facilities, goods, and health services be provided to individuals of appropriate quality. Regarding the prevalence of Covid19 , it can be said that all governments are obliged to take all necessary measures to deal with, track and treat this disease. Due to the limited number of hospital beds, the Italian government has recently adopted a policy to allow hospitals to admit patients with Covid19. ${ }^{18}$ Given that the right to health and treatment belongs to all human beings, it

17 UN General Assembly, international covenant on Economic, Social and cultural rights, 16 December 1966, Treaty Series, vol. 993, p.3.

18 Gostin, Lawrence O. "The human right to health: a right to the" highest attainable standard of health"." The hastings center report 31.2 (2001): 29-29. seems that this decision of the Italian government is a violation of the right to health because no government can deprive any individual of the right to treatment. Governments, both individually and collectively, are primarily responsible for ensuring the right to health. Governments have to respect and enforce the right to health promptly. Concerning Covid-19 disease, governments are required to fully equip hospitals and health care facilities and provide hospitals and treatment facilities with the necessary facilities and services to treat the disease.

On the other hand, if the equipment of medical centers and hospitals is not sufficient for screening and treatment of Covid-19 disease, the right to health is violated. Also, if hospitals and treatment centers are overcrowded, such a situation can lead to Covid-19. In South Africa, for example, it has been observed that medical centers and hospitals are overcrowded. Such a situation in South Africa could lead to a violation of the right to healthcare. ${ }^{19}$

\section{b. Covid-19 Test of accountability of modern governments}

Many governments have been criticized for not being serious enough to deal with the Covid-19. For example, the United States president (Donald Trump) has been widely criticized for his statements in handing over governments for early social restrictions. In quarantine, the fight against Covid-19 is required to implement measures related to the public health of social distances and travel bans. ${ }^{20}$

19 Montel, Lisa, et al. "The Right to Health in Times of Pandemic: What Can We Learn from the UK's Response to the COVID-19 Outbreak?." Health and Human Rights 22.2 (2020): 227.

20 Ibid 
In many countries, hospitals and private treatment centers are in charge of health and wellness. In these countries, private companies, pharmaceuticals, and private insurance companies are in charge and are considered at the helm of the health sector. In such countries, the government of health and treatment is obliged to fulfill its duty to guarantee the right to health. The United Nations Guide to Trade and Human Rights principles also reaffirm the government's role in ensuring the right to health. Accordingly, the government must ensure that private institutions and pharmaceutical companies do not rightly harm people's health. This state's task is of great importance because private companies are in charge of public health in many countries. Governments have taken different approaches to the Covid-19. Spain, for example, nationalized private hospitals to expand its medical and treatment capacity. ${ }^{21}$ In the United Kingdom, the government has entered into several agreements with private hospitals that require private hospitals to treat and provide nonprofit Covid-19 health care. ${ }^{22}$ In addition, governments have taken measures to counter the profiteering and opportunism of private companies. For example, the Bangladeshi government has banned private laboratories from conducting Covid-19 diagnostic tests. ${ }^{23}$

The reason for this decision was that private laboratories might not be able to

21 OHCHR. "COVID-19: States should not abuse emergency measures to suppress human rightsUN experts." (2020).

22 Ibid.

23 Karim, Mohammad Rezaul, Mohammad Tarikul Islam, and Bymokesh Talukder. "COVID-19' s impacts on migrant workers from Bangladesh: In search of policy intervention." World Development 136 (2020): 105123.

24 United Nations. (2011). Guiding principles on business and human rights: Implementing the United Nations "Protect, Respect and Remedy" framework. perform such tests properly. ${ }^{24}$ In addition, private hospitals and pharmaceutical companies are responsible for respecting the right to health. In other words, the primary responsibility of governments to protect the right to health does not negate the direct responsibility of private companies. The principles of the United Nations Guide also emphasize the direct responsibility of private companies in safeguarding the right to health to support public health care at a reasonable price. ${ }^{25}$ It is also obligated to provide medical items and goods to governments to ensure the right to health to make the most of its resources. For this reason, governments should ensure that, first, they admit private hospitals for patients with Covid-19. Second, private hospitals do not impose exorbitant costs on patients with covid-19. ${ }^{26}$

Nevertheless, governments in practice have faced such a dilemma. In India, for example, a private hospital refused to accept Covid-19, which was in dire need of treatment. ${ }^{27}$ There is a misconception among some that governments are committed to protecting the right to health (related to soft rights). The result of such a perception is that governments' soft commitment to guaranteeing the right to health depends on the resources and capacity of the state, and states can claim that they have not yet reached the capacity to guarantee the right to health. 28 The reason for such a misconception is that, firstly, according to the

25 Montel, Lisa, et al. "The Right to Health in Times of Pandemic: What Can We Learn from the UK's Response to the COVID-19 Outbreak?." Health and Human Rights 22.2 (2020): 227.

26 Ibid

27 Gauttam, Priya, et al. "Public health policy of India and COVID-19: Diagnosis and prognosis of the combating response." Sustainability 13.6 (2021): 3415.

28 Meier, Benjamin Mason. "The highest attainable standard: advancing a collective human right to public health." Colum. Hum. Rts. L. Rev. 37 (2005): 101. 
Covenant on Economic, Social and Cultural Rights, governments have recognized the highest standard of physical and mental health, second, the Contracting States to the covenant are expressly obliged in Article 2, paragraph 1 , to make use of the maximum resources available to them. ${ }^{29}$ Thus, governments are obliged to make the most of the available resources and have the duty to expand their existing resources to fight infectious diseases through international cooperation. ${ }^{30}$ For this reason, governments are obliged to use all available resources to combat the Covid-19. The resources available to governments are varied. These resources include financial, natural, human resources (physicians and nurses), technology resources (control and testing devices), and information resources (information on covid-19 outbreak). ${ }^{31}$ Thus, states are obliged to use all available resources to combat the Covid-19. Following Article 2, paragraph 1 of the Covenant on Economic, Social, and Cultural Rights, states must exercise the rights outlined in the covenant individually. The Committee on Economic, Social, and Cultural Law has considered the task of governments on international cooperation. In the case of Covid-19, governments are required to work together to combat the deadly virus and coordinate their efforts to combat Covid-19, in particular through the World Health Organization, and take the necessary measures to protect health. In general, physicians and nurses are more vulnerable than other social groups, because they are

29 Sepúlveda, M. Magdalena, and María Magdalena Sepúlveda Carmona. The nature of the obligations under the International Covenant on Economic, Social and Cultural Rights. Vol. 18. Intersentia nv, 2003.

30 Brodeur, Abel, et al. "A literature review of the economics of COVID-19." Journal of Economic Surveys 35.4 (2021): 1007-1044. seriously exposed to the Covid-19. They are more likely to become infected with the deadly disease. Thus, governments are obliged to inform the medical staff about the dangers of the virus before starting work in a hospital setting. Also, the necessary equipment, including masks, should be provided to the medical and treatment staff. Finally, in the field of human rights, the right to information is also of great importance. Article 19 of the Universal Declaration of Human Rights and Article 19 of the Covenant on Civil and Political Rights imply the existence of such a right. Governments must provide complete and comprehensive information on the prevalence of the disease to the public and provide the public with all necessary information, such as health precautions, to combat the Covid-19. Therefore, the public media, especially the national radio and television, have a duty to provide the public with the necessary information to combat the Covid-19. ${ }^{32}$

\section{c. Restrictions and suspensions of some human rights due to the Covid-19 emergency}

\section{1) Hermeneutic self-sufficiency of human rights: suspension of rights}

At the time of the outbreak of epidemics, government action to protect people's health can lead to human rights violations. For example, creating quarantine and social isolation may conflict with the right to free movement. In such a situation, Article 12 paragraph 3 of the Covenant on

\footnotetext{
31 Montel, Lisa, et al. "The Right to Health in Times of Pandemic: What Can We Learn from the UK's Response to the COVID-19 Outbreak?." Health and Human Rights 22.2 (2020): 227.

32 Ibid.
} 
Civil and Political Rights allows the exercise of certain rights to be restricted. Of course, experts in international law have issued a joint statement stating that the response to the spread of epidemics must be proportionate, necessary, and non-discriminatory. ${ }^{33}$

After the outbreak of covid-19, many governments have imposed restrictions on some human tricks and suspended some of them. There has been much debate about the legitimacy of the suspension of human rights during a state of emergency. In our time, many have suspended some human rights by declaring a state of emergency due to the outbreak of the Covid-19. States, in particular, have suspended or restricted freedom of movement and assembly to prevent the spread of the virus. For example, according to Article 12, paragraph 3 of the Covenant on Civil and Political Rights, States are permitted to impose restrictions on freedom of movement, subject to conditions, particularly the principle of necessity and proportionality, to maintain order security and public health. Article 4 of the Covenant on Civil and Political Rights defines the suspension of human rights in the event of a life-threatening emergency. Following paragraph 1 of this article, in the event of a general national emergency, the States Parties to the covenant may take steps to circumvent the covenant's provisions and suspend certain human rights by formally declaring such a situation. ${ }^{34}$

General Theory 29 of the Human Rights Committee, by explaining Article 4 of the Covenant on Civil and Political Rights, discusses the suspension of human rights during a state of emergency. According to

33 UN General Assembly, international covenant on civil and political rights, 16 December 1966.

34 OHCHR. "COVID-19: States should not abuse emergency measures to suppress human rightsUN experts." (2020). paragraph 2 of General Theory No. 29 of the Human Rights Committee, there must be measures related to the suspension of human rights. Second, the state of emergency must be so important that it endangers national life and an exceptional moment. Third, states must act within the framework of the constitution in times of emergency, and their actions can in no way go beyond the law. ${ }^{35}$

According to paragraph 3 of General Theory No. 29 of the Human Rights Committee, any riot or calamity cannot be described as a general state of emergency. Chaos and natural or manufactured disasters must have reached such an important level that they affect national life. According to paragraph 4 of the above general theory, exceptional and temporary measures must be commensurate with the state of emergency. This means that the duration and geographical scope of the state of emergency must be limited and adhered to by states. When declaring a state of emergency, the principle of proportionality, following paragraph 5 of General Theory No. 29, states must have sufficient justification for declaring a state of emergency. Declaring a state of emergency is a completely exceptional situation, and governments can only declare such a situation if necessary. Thus, in times of emergency, the suspension of human rights must be interpreted so that they can only suspend the legal group whose suspension is necessary to overcome the crisis. In addition, according to Article 4 paragraph 1 of General Theory 29 of the Human Rights Committee, States must adhere to the principle of non-discrimination when suspending their rights; This means

35 Ramcharan, Bertrand, and Bertrand G. Ramcharan. Contemporary Human Rights Ideas: Rethinking theory and practice. Routledge, 2008. 
that when human rights are suspended, they cannot impose restrictions based on race, color, gender, language, religion, and social status. Paragraph 2 of Article 4 of the same theory explicitly states that certain rights, such as the right to life, the prohibition of torture, and the prohibition of slavery, cannot be suspended. It should be noted that some economic, social, and cultural rights, like some civil and political rights, are nonsuspended; Legal doctrine calls these inalienable rights "minimum inherent rights." "Minimum inherent rights" are those classes of economic, social, and cultural rights that cannot be suspended and that restrictions cannot be imposed on them. ${ }^{36}$ "Minimum inherent rights" are also obligated, not gradually, to the immediate realization of "minimal inherent rights." For example, access to health care, the right to healthy food, shelter, and finally, the right to drinking water.

Legal rights are irrevocable, and governments cannot suspend such rights, even in a state of emergency. In the final analysis, the authors believe that the inability of some economic, social, and cultural rights to be suspended is because they are righthanded over to life. In simpler terms, some rights, such as the right to shelter, food, and safe drinking water, are so important that the right to life depends entirely on their observance. In addition to the Covenant on Civil and Political Rights, some regional human rights treaties also provide a state of emergency. For example, Article 27 of the

36 UN Human Rights committee, CCPR General comment No.29: Article 4: Derogations during a state of emergency, 31 August 2001.

37 Gorski, Philip. American covenant. Princeton University Press, 2019.

38 Mitchell, Rob D., et al. "Impact of COVID-19 State of Emergency restrictions on presentations to two Victorian emergency departments."
American Covenant on Human Rights and Article 15 of the European Covenant on Human Rights explicitly state that states may suspend the exercise of certain human rights by declaring a state of emergency. ${ }^{37}$

The constitutions of the world countries have also considered the state of emergency and explained its legal status. In general, a state of emergency is when a country goes out of its normal and current state and gets into a deep crisis. ${ }^{38}$ For example, in the event of armed conflict, natural disasters such as floods, earthquakes, droughts, and widespread terrorist attacks, countries become out of their current state and fall into crisis and state of emergency. ${ }^{39}$ In the current situation, some governments have suspended some human rights and freedoms by declaring a state of emergency because the Covid-19 has taken countries out of their normal state. Throughout history, legal thinking in the field of emergency has evolved. In the nineteenth century, the idea of the absolute sovereignty of states had many supporters among thinkers. ${ }^{40}$ For this reason, the philosophy of declaring a state of emergency in maintaining absolute sovereignty and political power was abandoned. In nineteenth-century history, when the existence of a government was in jeopardy, governments declared a state of emergency to maintain it. Of course, in that century, the idea of absolute sovereignty was also critical, and some states, including the United States, had delegated power to the president in the twentieth century to declare

Emergency Medicine Australasia 32.6 (2020): 1027-1033.

39 Kuniya, Toshikazu. "Evaluation of the effect of the state of emergency for the first wave of COVID-19 in Japan." Infectious Disease Modelling 5 (2020): 580-587.

40 Goodhart, Arthur. "The rule of law and absolute sovereignty." Annales de la Faculté de Droit d'Istanbul. Vol. 9. No. 12. 1958. 
a state of emergency under congressional oversight. ${ }^{41}$ Karl Schmidt also strongly defended the theory of absolute sovereignty. In the view of Karl Schmidt Reich, President of Germany Weimar's, he had broad powers in declaring a state of emergency because such powers were necessary to maintain German and Weimar rule. In practice, following the German Weimar's constitution, the president had broad powers to declare a state of emergency and determine its provisions, and in an emergency could even suspend individual and social rights and freedoms. In the twentieth century, the theory of broad sovereignty in declaring a state of emergency was gradually challenged. The new idea was based on the premise that the philosophy of declaring a state of emergency is not to maintain political sovereignty and power. Instead, the philosophy of declaring a state of emergency is to protect the republic, the rule of law, and democracy. ${ }^{42}$ For this reason, in the twentieth century, the powers of governments to declare a state of emergency were limited and monitored. There is now a belief that the state of emergency should be subject to the rule of law and cannot be considered as such. For example, in many European countries, two exceptional law cases can be sued against the government, and its decision to suspend the law overturned in court. ${ }^{43}$ In the following, some examples of constitutions of countries in the face of an emergency are discussed. In the United States, the state of emergency has long been based on the separation of powers, with the legislature (Congress) and the judiciary (US Supreme Court) overseeing the

41 Fisher, Louis. "Delegating Power to the President." J. Pub. L. 19 (1970): 251.

42 Schweitzer, Carl C. "Emergency Powers in the Federal Republic of Germany." Western Political Quarterly 22.1 (1969): 112-121.

43 Ibid president's powers to run the country during a state of emergency. Under the US Constitution of 1787, the extension of the powers of the United States president in an emergency was possible only with the permission of the US Congress, and the president could not arbitrarily extend his powers under the state of emergency. ${ }^{44}$

In 1861, just in time for the crisis of the American Civil War, the Supreme Court ruled that ordinary citizens could not be tried in military courts unless there was a general court. In France, Article 16 of the French Constitution legally defines a state of emergency. According to this article, "When the institutions of the republic, the independence of the country, the territorial integrity of the fulfillment of international obligations are seriously and immediately threatened, and the current functioning of the public forces arising from the constitution is disrupted, the president may be

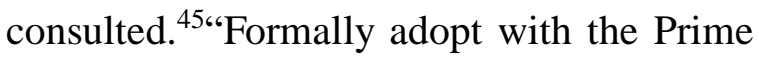
Minister, the Speakers of the Houses, and the Constitutional Council. [In the event of a state of emergency], the president is obliged to inform the nation of such a decision; The adoption of such measures must be inspired by the guarantee of the public forces emanating from the constitution, [also], be set in the shortest possible time and indicate the means of implementing its mission. ${ }^{46}$ The Constitutional Council will be the consulting party [in making such a decision]; Parliament will form a council by exercising its full rights; The National Assembly cannot be dissolved during the exercise of exceptional powers; Thirty days after the exercise of the

44 European convention for the protection of Human Rights and Fundamental Freedoms, 4 November 1950.

45 Giacomo, Delledonne," History and concepts of emergency", oxford constitutional law, August 2016, p. 4.

46 Ibid 
special powers, the Constitutional Council may, at the request of the Speaker of the National Assembly, the Speaker of the Senate, sixty deputies or sixty senators, consider the need for a state of emergency. That council is obliged to express its public opinion on the state of emergency as soon as possible. "The Constitutional Council has full authority to review and comment, and to comment under the same conditions within sixty days after the exercise of the exceptional powers or at any time after this period." As stated in Article 16 of the French Constitution, the declaration of a state of emergency by the president of this country is completely temporary and exceptional. The president is obliged to observe substantive and formal conditions in declaring a state of emergency. In essence, the declaration of a state of emergency is possible only if the institutions of the French Republic or the territorial integrity of France are under threat. ${ }^{47}$ In addition, the President of France can declare a state of emergency if it poses a serious and immediate threat to the national destiny of that country. ${ }^{48}$ For this reason, even if there is a threat to the national destiny of France, but the threat is not serious and urgent, the president cannot declare a state of emergency. Formally, the President of France is obliged to comply with certain conditions in a state of emergency. Therefore, the President of France can declare an emergency only after consulting the Prime Minister, the Speakers of the Houses (Senate and National Assembly), and the Constitutional Council. In addition, the powers of the President of France in declaring a state of emergency have been monitored; So that the Constitutional Council

47 Ex parte Merryman (1861), in: Ibid., p. 4.

48 Ibid of that country can review and review the state of emergency and even if the declaration of a state of emergency is not following the constitution, can lift the state of emergency. Therefore, as can be seen, the powers of the President of France in declaring a state of emergency are not limited and are subject to the rule of law. ${ }^{49}$

The Constitution of the Islamic Republic of Iran also addresses the issue of declaring a state of emergency in Article 79. The principle reads: "The establishment of military government is prohibited. In case of war and emergencies such as this, the government has the right to temporarily impose the necessary restrictions with the approval of the Islamic Consultative Assembly, but its duration may not exceed thirty days, and if the need persists, the government is obliged to retake it from the assembly. As used in Article 79 of the Constitution, if there is a state of emergency in the country, the restrictions are imposed only as necessary, and the government has no right to impose excessive restrictions based on the state of emergency. Also, according to Article 79 of the Constitution, the declaration of a state of emergency is temporary, and the government cannot extend the state of emergency indefinitely. Therefore, the Iranian constitution has accepted the principle of the exceptional and temporary nature of the state of emergency following international standards. ${ }^{50}$

Currently, 20 countries worldwide have officially declared a state of emergency due to the outbreak of Covid-19 citing the suspension of some human rights. Due to the endangerment of national life, this group of countries officially declared the state of

49 La constitution de la république française, constitution du 4 octobre 1958, version mise à jour en janvier 2015.

50 Ibid. 
emergency caused by the outbreak of the Covid-19 to the United Nations, the Council of Europe, and the Organization of American States. They have declared a state of emergency concerning the suspension of some human rights. ${ }^{51}$

In addition, ten member states of the Organization of American States have so far declared a state of emergency, including the number of states that have suspended some human rights. The outbreak of the Covid$19^{52}$, which has declared a state of emergency, and some human rights have been suspended, has been unprecedented throughout history. A declaration of a state of emergency can be dangerous and a threat to human rights. When a state of emergency is declared, those in power will threaten legitimate political power under the pretext of spreading infectious diseases. ${ }^{53}$ In such a situation, those in power can use their power to suppress their opponents, dissolve parliament, delay elections, and pave the way for establishing dictatorship and tyranny. Therefore, a state of emergency must be provided immediately and immediately. Bring. Not be allowed to extend the state of emergency indefinitely; The rule of law must fully govern the state of emergency, and government officials must act within that framework within the law. ${ }^{54}$

\subsubsection{Suspension of Rights}

51 Martin Scheinin, Covid-19 Symposium: To derogate or Not to derogate, in: Covid-19 and international law, opinion juris symposium, p. 122.

52 The names of the countries that have declared a state of emergency in relation to the European Convention on Human Rights are: Albania, Armenia, Estonia, Georgia, Latvia, Moldova, Northern Macedonia and Romania.

53 Recent list of countries are: Argentina, Bolivia, Chile, Colombia, Ecuador, El Salvador, Guatemala, Honduras, Panama and Peru. Six of the ten countries have announced to the United
The question also arises as to whether, in a crisis caused by the outbreak of covid19 , governments are obliged to declare a state of emergency and consequently suspend certain human rights, such as the right to travel. In this case, the tricks' suspension does not seem relevant. This means that if the protection of citizens' right to health requires a declaration of a state of emergency, governments are obliged to suspend certain human rights, such as free movement and assembly, by declaring a state of emergency. Otherwise, if governments can effectively deal with the spread of infectious diseases without declaring a state of emergency, declaring a state of emergency does not seem necessary. ${ }^{55}$

As detailed in the previous article, Article 4, paragraph 1 of the International Covenant on Civil and Political Rights provides the suspension of human rights under certain conditions within States' competence. Nevertheless, declaring a state of emergency and consequently suspending some rights (albeit only in situations where national life is at stake) is justifiable. ${ }^{56}$ Therefore, the necessity of suspending some tricks in such circumstances (with due regard) and not voluntary jurisdiction is itself a necessity of human rights. The necessity of human rights obliges states to declare such a situation and consequently take appropriate measures within the framework of the restrictions provided for in Article 4.

Nations that they are suspending some of the human rights under the Covenant on Civil and Political Rights. The list of these countries includes: Armenia, Ecuador, Estonia, Guatemala, Latvia and Romania.

54 Ibid.

55 Ibid.

56 Joseph, Sarah, and Melissa Castan. The international covenant on civil and political rights: cases, materials, and commentary. Oxford University Press, 2013. 
Accordingly, the appearance of Article 4 should not be construed as meaning the voluntary competence of States, which means their exclusive authority and, of course, their human rights obligations. Such an interpretation represents the hermeneutic self-sufficiency of the human rights system within the interpretive system of rights conflict. $^{57}$

\subsubsection{Security Council in the face of the Covid-19}

Following the outbreak of the Covid19, public opinion turned to the World Health Organization; What is more, this organization has the main responsibility to maintain global health. For this reason, the World Health Organization (WHO) announced on 30 January 2020 that the outbreak of the Covid-19 is an international crisis and could pose a serious threat to public health. However, the potential capabilities of the UN Security Council in dealing with the outbreak of the Covid-19 should not be overlooked. Although the Security Council is primarily responsible for maintaining international peace and security and often engages in armed conflict situations, the Security Council has resources that can be used to combat the spread of communicable diseases. Although the main task of the Security Council is to safeguard international peace and security, the council has interpreted its competence broadly, sometimes concerning the prevalence of infectious diseases, in the name of international security. In the West ${ }^{58}$, the story of the Security Council entering the field of the fight against communicable diseases goes

57 Ibid.

58 Kondoch, Boris. "covid-19 and the Role of the Security Council as Global Health Peacekeeper." Journal of International Peacekeeping 23.1-2 (2019): 105-116. back to the outbreak of Ebola in Africa in 2014; In that year, the Security Council, for the first time, adopted a resolution declaring the Ebola outbreak in West Africa a threat to peace and national security. Introduction to the resolution to justify that the outbreak in West Africa is primarily considered a threat to international peace and security, the following points are made: The outbreak of Ebola in West Africa endangers the stability of vulnerable countries; The prevalence of this disease has contributed to social unrest; The prevalence of Ebola in West Africa has harmed the situation of women; Countries infected with the Ebola virus do not have the capacity and capacity to fight the virus; The prevalence of Ebola has had several negative effects on food security, business security, and travel security. The final section of Resolution 2177 includes the following measures to address the Ebola outbreak: ${ }^{59}$

- Governments affected by the Ebola virus are encouraged to address the outbreak of the disease, such as diagnosis, quarantine, treatment of patients, protection of hospital staff, and staff training.

- Governments infected with the Ebola virus are encouraged to reduce the spread of the Ebola virus to political, security, social, economic, and humanitarian dimensions;

- All Members of the United Nations are called upon to lift the border restrictions imposed as a result of the Ebola outbreak;

- All Members of the United Nations are requested to provide the necessary medical equipment and facilities to

59 UN Security Council, Resolution 2177, 18 September 2014, on the outbreak of the Ebola Virus in , and its impact on west Africa. 
the Governments affected by the Ebola virus;

- All Members of the United Nations are requested to implement the recommendations of the World Health Organization following the 2005 World Health Regulations on Tackling the Ebola Outbreak in West Africa.

In addition, Resolution 2177 established a special body called the United Nations Mission against Ebola. The question now is, is the Covid-19 essentially comparable to the Ebola virus? The fact is that Covid-19 and Ebola have considerable differences: First, the Ebola-related mortality rate is higher than that of covid-19. Second, the Ebola virus only spread to a specific geographical area of the world (West Africa). However, the prevalence of the Covid-19 is international and has spread to almost all world countries. Also, the efforts of West African countries against Ebola have been relatively successful. Instead, government measures against the Covid-19 have not yet been successful, and countries worldwide are engaged in various dimensions to combat this dangerous disease. Although the death rate from covid-19 is lower than from Ebola, the death rate from covid-19 is higher than all deaths from Ebola and is also increasing. This is because the prevalence and rate of Covid-19 spread are higher than that of Ebola. In addition, the Covid-19 can cause serious disruptions to a country's health system. Hospitals in the Covid-19 countries are full of patients infected with the virus. In such circumstances, on the one hand, the

60 The United Nations Missions for Ebola Emergency response (UNMEER).

61 Kaufman, Kenneth R., et al. "A global needs assessment in times of a global crisis: world psychiatry response to the COVID-19 pandemic." BJPsych open 6.3 (2020). medical staff of the hospitals is always faced with difficult decisions in the correct allocation of the hospital staff; Because hospital beds are limited. However, the number of patients infected with covid-19 is high, and physicians and treatment staff often wander to which patient to assign limited hospital admissions.

On the other hand, the decision to allocate hospital beds has negative psychological consequences; For example, a doctor who decides to give a bed to a young person instead of a middle-aged person may suffer a guilty conscience and eventually lose their job. ${ }^{60}$ Hospital overcrowding and hasty decisions may make the medical staff miserable in the meantime and reduce the quality of the work of therapists and physicians. ${ }^{61}$ Governments inevitably take steps to counter the rapid spread of the Covid-19, such as blocking borders, restricting public gatherings, and sometimes restricting trade in goods. Such measures may have several negative consequences on countries' economies and lead them to a crisis of recession and unemployment, which can already be seen these negative consequences in many countries. The fact is that the Security Council can play an important role in combating the spread of the Covid-19. ${ }^{62}$ On the one hand, the Security Council has experience dealing with the Ebola virus and can prioritize its fight against the Covid-19. On the other hand, given the international dimension of the covid-19 crisis, the Security Council can describe the outbreak of covid-19 as a threat to international security and, in Chapter VII of

62 Haque, Mainul. "Combating COVID-19: a coordinated efforts of healthcare providers and policy makers with global participation are needed to achieve the desired goals." Bangladesh Journal of Medical Science (2020): 01-05. 
the UN Charter, call on UN member states to take binding measures. Adopt this field. In other words, in the form of Chapter VII of the Charter of the United Nations, the Security Council can establish binding legal obligations for members of the United Nations. To date, governments' efforts to combat covid-19 have often been individual, and governments have engaged less in international cooperation to combat covid19. The Security Council requested that in addition to the International Atomic Energy Agency's ongoing inspections in Iran, it monitors Iran's compliance with "the steps required by the IAEA Board." The Security Council requested that in addition to the International Atomic Energy Agency's ongoing inspections in Iran, it monitors Iran's compliance with "the steps required by the IAEA Board." It can also strengthen the position of the World Health Organization against Covid-19 and, by adopting a resolution, call on all member states of the United Nations to consider and implement the recommendations of that organization. ${ }^{63}$

Under Article 25 and 48 of the Charter of the United Nations, States Parties undertake to implement the decisions of the Security Council. In addition, under Article 103 of the Charter of the United Nations, the obligations of States under the charter take precedence over other obligations of States. For this reason, any decision taken by the Security Council to address the further spread of the Covid-19 (Article 103 of the Charter) will take precedence over other obligations of States. In particular, prioritizing the obligations of governments under the charter

63 Kondoch, Boris. "covid-19 and the Role of the Security Council as Global Health Peacekeeper." Journal of International Peacekeeping 23.1-2 (2019): 105-116.

64 United Nations, Charter of the United Nations, 24 October 1945, Article 103. in the fields of investment, trade, and aviation is of particular importance. ${ }^{64}$ Explain that governments' decisions to combat the outbreak of covid-19 may conflict with their trade, investment, and aviation commitments.

For this reason, the Security Council, following Article 103 of the Charter, can facilitate the fight against the spread of the Covid-19. However, any action by the Security Council to combat the increased prevalence of the Covid-19 requires the consent of all five permanent Security Council members. For a long time, not only was there no spirit of cooperation among the permanent members of the Security Council, but the members of the Security Council accused each other of making biological weapons against human society. Some Chinese officials have accused US military agencies of building a biological weapon called the Covid-19. In contrast, the current US President (Donald Trump) also named the Covid-19 a Chinese virus and blamed the Chinese authorities for its spread. ${ }^{65}$ After a long debate and the veto of a draft resolution by the United States on Friday, 9 May 2020, urging governments to combat the effects of the Covid-19, the Security Council was finally forced to adopt a resolution under pressure from the pressure the international public opinion. ${ }^{66}$

UN Security Council inefficiencies The first question that comes to mind is whether the UN Security Council must deal with global health crises. In the age of globalization, the rapid movement of people has increased the prevalence of epidemics

65 https://www.cnn.com/2020/05/09/politics/usrejects-un-coronavirus-resolutionchina-who / index.html.

66 see the Resolution (S / RES / 2532) from July 1, 2020. 
and even turned them into pandemics. A phenomenon that endangers everyone's health has become one of the concerns of the international community. For example, in the first two decades of the third millennium, SARS (2003), avian influenza (2009), cholera in Haiti (2010), and in Yemen (2018 and beyond), Ebola in Africa and Latin America (2019). Finally, covid-19 (2020), Zika (2014) ${ }^{67}$ posed a serious threat to human health; AIDS should not be overlooked either. ${ }^{68}$ The Charter of the United Nations (Article 55) shows that this organization needs the principle of equal rights of the people in determining their destiny to create conditions of stability and prosperity to ensure peaceful and friendly relations based on respect. ${ }^{69}$

It does not appear in Chapters 6 and 7 of the charter, which is specific to the powers of the Security Council but requires the United Nations to take action to address public health problems. Obviously, as one of the main pillars of this organization, the Security Council, The procedure of this pillar also confirms such an attitude towards Article 55. The Security Council's broader interpretation of "international peace and security" has made it possible for the pillar to operate in many areas, including poverty, the fight against international crime, terrorism, human rights and humanitarian violations, environmental degradation, and so on. Enter. In addition to the Security Council, the World Health Organization (WHO), as one of the specialized agencies of the United Nations,

67 Zika is a disease that begins with the bite of an insect and kills an infected person in a short time. Thousands of people in Latin America have died from the disease.

68 AIDS first died in 1981 in California (USA). Nevertheless, the Security Council draws attention to the danger of its spread with the adoption of Resolution 1308 of 17 July 2000. The Council also reiterated in 2011 the danger of the spread of also recognizes the link between health protection and peacekeeping. It should also be noted that the World Health Organization (WHO) Regulations, which make such a relationship well known, apply to the prevalence of all pandemics, regardless of their source. Despite such a solid foundation and existing procedure for Security Council intervention, this pillar has long been reluctant to declare that it is safe from a dangerous pandemic called covid-19, which has indiscriminately targeted and killed humanity without any distinction.

Finally, on 1 July 2020, with the adoption of Resolution $2532^{70}$, while declaring that the council has the primary responsibility for maintaining international peace and security, he emphasized the need to strengthen national, regional, and global cooperation and solidarity that threatens international peace and security. The Security Council requested that in addition to the International Atomic Energy Agency's ongoing inspections in Iran, it monitors Iran's compliance with "the steps required by the IAEA Board." Of course, the council declares that military operations (s) against ISIL, al-Qaeda, and Jabhat al-Nusra and other individuals, groups, agencies, and institutions related to al-Qaeda or ISIL, and other terrorist groups, has been carried out by the council. Furthermore, these operations can continue against them. Finally, the council calls on the Secretary-General to instruct the peacekeepers to support their local authorities and governments to combat

AIDS, both because of the hostilities and not as a threat to peace.

69 Klabbers, Jan. An introduction to international organizations law. Cambridge University Press, 2015.

70 Daugirdas, Kristina. "How and Why International Law Binds International Organizations." Harv. Int'l LJ 57 (2016): 325. 
the Covid-19 pandemic. With the passage of such a resolution, which appears to have been issued under Chapter VII of the Charter (because the Security Council stated in the preamble that its long-running expansion into the Covid-19 Pandemic threatens international peace and security), there are still no tangible effects. Not visible against the covid-19 pandemic. A look at the performance of governments and the Security Council shows that their willingness to take action is more like a mirage, which ultimately leads the thirsty to death. Governments have shown that they always maintain a margin of maneuver to respond to health-related threats, and that is to impose rules that are not necessarily in line with international obligations in the field of intellectual property rights in their relations. The conclusion of the TRIPS Plus trade agreement, which has made it much more difficult to break the rules of ordinary TRIPS, shows that what matters to them is not man but power and the economy. Now, among the states, those who have access to important financial instruments and scientific and research facilities to combat the covid-19 pandemic, and who are also permanent members of the Security Council with a privileged veto, decide instead of "based on," Do not even agree on the title of the resolution. The United States has even gone so far as to threaten to cut the World Health Organization (WHO) budget altogether under the pretext of supporting China. However, the Security Council requested that in addition to the International Atomic Energy Agency's ongoing inspections in Iran, it monitors Iran's compliance with "the steps required by the IAEA Board." The council can adopt two categories of measures: - The first category includes economic decisions and restrictions, including economic measures, mandatory quarantine, travel bans, etc., to ensure public health and, of course, without creating fear and panic. It is unnecessary to isolate and even enforce civilian coercive measures (as enshrined in Article 41 of the Charter) and to use the pressure of world public opinion on governments that refuse to implement those decisions. If the council itself does not have the power of expert discretion, it can impose at least the recommendations of the World Health Organization on governments in the form of binding resolutions.

The second category is the use of new measures. The Security Council requested that in addition to the International Atomic Energy Agency's ongoing inspections in Iran, it monitors Iran's compliance with "the steps required by the IAEA Board." For example, it was possible to withdraw from its adopted resolution from the "TRIPS" and "TRIPS Plus" treaties. Since, following Article 103 of the Charter, the obligations of States under the charter take precedence over their other agreements, as long as there is a covid-19 pandemic, it is possible to derogate from these treaties. In addition, the Security Council could ask the International Monetary Fund (IMF) to provide free or interest-free financial assistance to needy governments or at least to repay their arrears. Finally, he asked them not only not to make their demands, but also to take action (including litigation) against those governments so that they could fight the covid-19 pandemic, regardless of such concerns. This is not a new proposal, of course.

The Security Council requested that in addition to the International Atomic Energy Agency's ongoing inspections in Iraq, that it monitor Iraq's compliance with "the steps required by the IAEA Board." However, the practice of the Security Council and Resolution 2532 show that it is reluctant to take such action in these cases. One of the 
Security Council's most important measures to combat the epidemic is Ebola, which shows that it has not gone beyond a few recommendations. The council first expressed concern about the onset of the Ebola epidemic in 2013, without entering Section 7 of the Charter. This pillar finally unanimously adopted Resolution 2177 on 18 September 2014, acknowledging the urgency of the Ebola situation and considering it a threat to peace. Despite this, the Security Council also emphasized this point in its statement; Security did not take any comprehensive and effective action on the dimensions and issues raised by the disease and merely raised a security debate without focusing on public health concerns. In other words, the council did not want to play the role of a "good ruler" and fight all aspects and effects of the disease, including security and public health. In the adopted resolution, the security aspects have been considered by the Security Council. The council justifies its entry by establishing a relationship between Ebola and the resurgence of armed conflict. However, it seems that the council begins its movement based on a health crisis and eventually ties it to a socio-economic and, in fact, security threat. The Security Council requested that in addition to the International Atomic Energy Agency's ongoing inspections in Iran, it monitors Iran's compliance with "the steps required by the IAEA Board." The council does not do so in Resolution 2177, tying its entry into the Ebola epidemic into a state of conflict and the possibility of a return to armed conflict in the countries involved, namely Guinea, Sierra Leone, and Liberia. The Security Council

\footnotetext{
NU.S/PRST/2014/24,21Nov 2014.

72 Quintana, Francisco-José, and Justina Uriburu. "Modest International Law: COVID-19, International Legal Responses, and
}

merely makes several recommendations with no legal obligation in its resolutions, and it does not take any coercive action. The council urges the governments involved in Ebola to take the necessary measures and urges other governments to assist them and coordinate UN action. In other words, the council does not solve the Ebola epidemic problem. $^{71}$

The Security Council requested that in addition to the International Atomic Energy Agency's ongoing inspections in Iran, it monitors Iran's compliance with "the steps required by the IAEA Board." This does not seem to be an excuse. The Security Council has no competence in the field of health ${ }^{72}$; That is why Article 12 of the "World Health Regulations" considers the declaration of an urgent state of public health on an "international" scale under the auspices of the World Health Organization. The task that the director-general of this organization has done well has declared covid-19 as a pandemic. Thus, with the announcement of this situation, the earlier entry of the Security Council based on "severity," "urgency," and "extraterrestrial effects" of covid-19 was well justified. Of course, restricting the Security Council from entering the realm of counter-pandemics in a "state of emergency" actually reduces the council's role to a practical one, which is often unrelated to these crises. It seems that the main factor in the entry of the Security Council into the realm of public health is not the extent of the crisis but its nature and danger to human life. ${ }^{73}$ Although the Security Council has finally been able to pass a resolution directly on the covid-19 pandemic, it must be said

\footnotetext{
Depoliticization." American Journal of International Law 114.4 (2020): 687-697.

${ }^{73}$ Spector, Hannah. "The significance of sense in the time of plagues: Curricular responsiveness to the Covid-19 crisis." Prospects (2021): 1-17.
} 
that this pillar is ultimately a central body whose actions are the main criterion for government action. In the current intergovernmental society, the state is still the main thinker and decision-maker. Can one hope for effective action from this idiot and Stephanie, who is almost 400 years old? Is it not time for individuals to save themselves by covid-19 by realizing their organized solidarity (for example, in the form of civil society) and ignoring the wishes and policies of governments? It seems that the hope for these 400-year-old Leviathans and their institutions is to be pounded. Covid-19 was the perfect means to unveil the ugly and dreadful face of this monster (government) ostensibly hidden behind institutional multilateralism (the Security Council) and to show the United Nations that this usurper (government) will never lead them to the goal of having the same health, real and lasting peace, material and spiritual well-being, and in a word, happiness. ${ }^{74}$

\section{Conclusion}

The future of contemporary international law in the face of the covid-19 dilemma is uncertain. However, the postcovid-19 era may be very similar to the precovid-19 era, both legally and in terms of the survival of international institutions. Nevertheless, other old-fashioned institutions will no longer have so much credibility with the world's public opinion. Public distrust will certainly not allow any authority to survive. Authorities lacking public trust must sooner or later disintegrate and join the history of history. The future of "international law" is clear. It is a right in which institutions from Westphalia and their ramifications will not have much room to thrive, even if they seem to continue to live a shameful life. Relevant, like the United Nations Security Council, have serious doubts. A group of countries has explicitly or implicitly stated that the World Health Organization and other institutions have not done their job properly dealing with covid-19 and have not effectively prevented its spread.

For this reason, many suggestions have been made to modify their optimal structure and function, especially in the case of the World Health Organization. In the future, it seems that the World Health Organization will be the focus of international law developments, and reforms will be made to strengthen the structure and improve its efficiency. This prediction is further reinforced by the fact that there is a risk of making microbial weapons. In the current situation, terrorist groups can endanger international peace and security by building laboratory viruses. Therefore, the World Health Organization structure must be strong and efficient enough to withstand the threats posed by the spread of these viruses. The World Health Organization (WHO) is expected to move from a passive and subsidiary state to play a more effective and important role in tackling the threat posed by the spread of epidemics. Legal Research Quarterly - Special Issue of Law and Covid19 The Covid-19 Problem in the Mirror of Contemporary International Law, In addition, the covid-19 phenomenon could transform the concept of international peace and security in the future. In the classical sense, armed conflict posed a serious threat to international peace and security. Gradually, however, the concept of international peace and security has become broader; So that some human problems such

\footnotetext{
74 https://www.cnn.com/2020/05/09/politics/usrejects-un-coronavirus-resolutionchinawho/index.html.
} 
as the spread of epidemic diseases can threaten the international community's security. Covid-19 has stopped the normal and current cycle of human life for several months. In the current situation, international law can consider the outbreak of covid-19 as a threat to international peace and security and, in the future, take measures to combat the spread of such pandemics. Achieving this requires a more efficient and effective World Health Organization. Of course, the future is unknown to man, and it is impossible to predict the future except in rare cases. What is said about the future is based only on suspicion; Suspicion also does not indicate certainty and, in the end, does not lead to much. In addition, the future of international law in the face of the Covid-19 depends partly on scientific and medical advances and its success in the manufacture and production of vaccines and therapeutic drugs. Regardless of the future, the Covid-19 has exposed the shortcomings of the past and the present; The effects of this deadly virus on the future of humankind will be revealed gradually and over time. The Covid-19 reminded humans that it is weak; What is more, in a short time, an extremely small virus could transform and defeat society with all its splendor and sophistication, and sophisticated technologies. The Covid-19 reminded the man that the destinies of all human beings are interdependent; Because the outbreak of covid-19 in one part of the world can affect the whole world and defeat and sadden.

For this reason, overcoming humanitarian crises requires genuine international solidarity and cooperation. Today, no state can overcome the humanitarian crisis alone, especially as the experience of right-wing governments has exposed the weakness of national selfishness and brought more scandal. If, until yesterday, the claimants of the revival of national interests at the cost of neglecting international institutions were seeking their national glory, the Covid-19 showed that the revival of national interests by disregarding the rights of the 19 The contemporary international is not compatible with international institutions. Conversely, for national peace and security, you must first think of international peace and security. Human encounters with human suffering throughout history have not been subject to a single pattern. Man has sometimes tried to improve his work by learning from the misery, defects, and crises. Sometimes this same man has not only not learned from the misery, shortcomings, and crises but has also insisted on the selfishness and shortcomings of his work. Will humans learn from the misery caused by the outbreak of the Covid19? Will governments wake up to widespread "international solidarity" to resolve the crisis after widespread deaths from the virus? This question is never simple; Throughout history, the human movement has been sometimes wise and sometimes irrational. In the future of international law, three possibilities are predictable and likely to occur: first, the possibility of strengthening policies based on national isolation; Second, strengthening policies based on international solidarity; Third, the transformation of the United Nations into a world parliament composed of representatives of the states and the true representatives of the peoples of the world. The first possibility is that the Covid-19 will make the hard walls of national selfishness harder and taller. The consequences of such a possibility are not far off; Right-wing governments will blame the spread of covid19 on overly open national borders, tightening borders, and tightening immigration policies. Far-right governments have long blamed the problems of their 
internal societies on the over-openness of national borders and over-compliance with the cumbersome provisions of international law. Likely, such states will further tap into the contractionary policies after the Covid-19 crisis subsides and further restrict the entry of migrants and refugees. As the US experience in cutting World Health Organization funding has shown, right-wing governments are likely to cut ties with the organization under the pretext of the Covid-19 outbreak or to undermine international institutions.

During the illness, irrational reactions to the covid-19 crisis even went so far as to veto a Security Council resolution calling for a temporary ceasefire to combat the Covid19. The second possibility is that the worldwide outbreak of the Covid-19 will realize and strengthen "true international solidarity" and strengthen global institutions. This possibility is reinforced by the fact that covid-19 is an international crisis that requires the participation and solidarity of the international community of states. If governments pursue solidarity rather than conflict politics, the World Health Organization will find its rightful place. Selfishness arising from national utilitarianism fails to overcome international crises. In such a situation, rationality emanating from human society can curb international crises. However, the outbreak of the Covid-19 has shown that existing international institutions are not efficient enough, at least in need of further reform and strengthening; However, one should not have much hope for them.

The third possibility is that, until the world is liberated from the hands of governments, it will transform the United Nations into a kind of world parliament composed of their representatives and the representatives of the people of the world (in the form of real civil societies). Adopt. This phenomenon can accelerate the process of "human rights-oriented international law." Paying attention to the health of all the world peoples as a factor in accelerating the humanization of international law will certainly be a decisive phenomenon in maintaining international peace and security. Here, the words of the famous German poet Goethe inevitably come to mind in his valuable work "Faust," which says: "Finally tell me who you are?" Furthermore, he answers: "I am a part of that force that always wants bad and always creates good." In other words, it is a force that thinks evil and creates good.

\section{REFERENCES}

Brodeur, Abel, et al. "A literature review of the economics of COVID-19." Journal of Economic Surveys 35.4 (2021): 1007-1044.

Bartolini, Giulio. "A universal treaty for disasters? Remarks on the International Law Commission's Draft Articles on the Protection of Persons in the Event of Disasters." International Review of the Red Cross 99.906 (2017): 1103-1137.

Daugirdas, Kristina. "How and Why International Law Binds International Organizations." Harv. Int'l LJ 57 (2016): 325.

Delledonne, Giacomo. "Crises, Emergencies and Constitutional Change." Routledge Handbook of Comparative Constitutional Change. Routledge, 2020. 245-260.

Fisher, Louis. "Delegating Power to the President." J. Pub. L. 19 (1970): 251.

Gostin, Lawrence O. "The human right to health: a right to the" highest attainable standard of health"." The hastings center report 31.2 (2001): 29-29. 
Gauttam, Priya, et al. "Public health policy of India and COVID-19: Diagnosis and prognosis of the combating response." Sustainability 13.6 (2021): 3415.

Goodhart, Arthur. "The rule of law and absolute sovereignty." Annales de la Faculté de Droit d'Istanbul. Vol. 9. No. 12. 1958.

Gorski, Philip. American covenant. Princeton University Press, 2019.

Haque, Mainul. "Combating COVID-19: a coordinated efforts of healthcare providers and policy makers with global participation are needed to achieve the desired goals." Bangladesh Journal of Medical Science (2020): 01-05.

Joseph, Sarah, and Melissa Castan. The international covenant on civil and political rights: cases, materials, and commentary. Oxford University Press, 2013.

Karim, Mohammad Rezaul, Mohammad Tarikul Islam, and Bymokesh Talukder. "COVID-19' s impacts on migrant workers from Bangladesh: In search of policy intervention." World Development 136 (2020): 105123.

Kondoch, Boris. "covid-19 and the Role of the Security Council as Global Health Peacekeeper." Journal of International Peacekeeping 23.1-2 (2019): 105-116.

Klabbers, Jan. An introduction to international organizations law. Cambridge University Press, 2015.

Kaufman, Kenneth R., et al. "A global needs assessment in times of a global crisis: world psychiatry response to the COVID-19 pandemic." BJPsych open 6.3 (2020).

Kuniya, Toshikazu. "Evaluation of the effect of the state of emergency for the first wave of COVID-19 in Japan." Infectious Disease Modelling 5 (2020): 580-587.

Kurniaty, R, "IHR 2005: Substantial Developments For International Law" 50, No. 4 (2021): 434-446, doi:https://doi.org/10.14710/mmh.50 .4.2021.434-446

Kusuma, FIS, et al "Examining on Indonesian Legal Challenges for Future Transnational Healthcare Service" DOI: http://dx.doi.org/10.21776/ub.blj.202 0.007.01.07

Meier, Benjamin Mason. "The highest attainable standard: advancing a collective human right to public health." Colum. Hum. Rts. L. Rev. 37 (2005): 101.

Mitchell, Rob D., et al. "Impact of COVID19 State of Emergency restrictions on presentations to two Victorian emergency departments." Emergency Medicine Australasia 32.6 (2020): 1027-1033.

Montel, Lisa, et al. "The Right to Health in Times of Pandemic: What Can We Learn from the UK's Response to the COVID-19 Outbreak?." Health and Human Rights 22.2 (2020): 227.

Odom, Jonathan G. "COVID-19 and the Law: A Compilation of Legal Resources." Available at SSRN 3588225 (2021).

OHCHR. "COVID-19: States should not abuse emergency measures to suppress human rights-UN experts." (2020). available at: https://www.ohchr.org/ EN/ NewsEvents/ Pages/ DisplayNews.aspx? News ID $=25722$ $\&$ LangID $=$ E.

Quintana, Francisco-José, and Justina Uriburu. "Modest International Law: 
COVID-19, International Legal Responses, and Depoliticization."

American Journal of International Law 114.4 (2020): 687-697.

Ramcharan, Bertrand, and Bertrand G. Ramcharan. Contemporary Human Rights Ideas: Rethinking theory and practice. Routledge, 2008.

Sepúlveda, M. Magdalena, and María Magdalena Sepúlveda Carmona. The nature of the obligations under the International Covenant on Economic, Social and Cultural Rights. Vol. 18. Intersentia nv, 2003.

Schweitzer, Carl C. "Emergency Powers in the Federal Republic of Germany." Western Political Quarterly 22.1 (1969): 112-121.

Scheinin, Martin. "COVID-19 symposium: to derogate or not to derogate?." (2020).

Spector, Hannah. "The significance of sense in the time of plagues: Curricular responsiveness to the Covid-19 crisis." Prospects (2021): 1-17.

UN Human Rights committee, CCPR General comment No.29: Article 4: Derogations during a state of emergency, (2001).

United Nations. Guiding principles on business and human rights: Implementing the United Nations "Protect, Respect and Remedy" framework (2011).

United Nations, Charter of the United Nations, 24 October 1945.

UN General Assembly, Universal Declaration of Human Rights, 1948.

UN General Assembly, international covenant on Economic, Social and cultural rights, 16 December 1966, Treaty Series, vol. 993.
UN General Assembly, international covenant on civil and political rights, 16 December 1966.

UN Security Council, Resolution 2177, 18 September 2014, on the outbreak of the Ebola Virus in, and its impact on west Africa.

Villarreal, Pedro A. "Pandemic: Building a Legal Concept for the Future." Wash. U. Global Stud. L. Rev. 20 (2021): 611.

Widadgo, Setyo, 2019, "International Law in the Dynamics of International Relations", UB Press, Malang.

World Health Regulations, International Health Regulations, 2005.

Zarifi, S., and K. Powers. "Human rights in the time of COVID-19: Front and centre. International Commission of Jurists, 6 April 2020." 